\title{
Awareness Regarding Pelvic Organ Prolapse Among Women Attending a Teaching Hospital in Chitwan
}

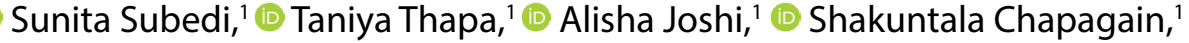 \\ (D) Sirjana Shrestha ${ }^{2}$
}

'Department of Nursing, Chitwan Medical College, Chitwan, Nepal

${ }^{2}$ Department of Nursing, College of Medical Sciences, Chitwan, Nepal

\section{ABSTRACT}

Objectives: Pelvic organ prolapse is the descent of one or more of the pelvic structures from the normal anatomic location toward or through the vaginal opening influencing the quality of life of women particularly among adults and old women in developing countries. We aim to assess the awareness regarding pelvic organ prolapsed among women attending in a teaching hospital, Chitwan so that necessary awareness program could be recommended if found unsatisfactory.

Methods: A descriptive cross-sectional study was done among 110 women attending Gynae Gynaecology Outpatient Department of Chitwan Medical College Teaching Hospital, Chitwan who participated voluntarily in face to face interview that used structured questionnaire from $1^{\text {st }}$ July to $5^{\text {th }}$ August, 2018 selected using consecutive sampling technique. Data was analyzed using descriptive and inferential statistics like frequency, percentage, mean, standard deviation, chi-square and fisher exact test.

Results: Among 110 respondents the median age was 37.0 years, 31.8\% were from the ages between $31-40$ years. Majority of the respondents were literate, $47.3 \%$ were housewife, $51.8 \%$ had first child between the ages of $20-24$ years, $46.4 \%$ had two children, $33.6 \%$ had abortion, $49.1 \%$ had heard about pelvic organ prolapse from friends and relatives and $6.4 \%$ were diagnosed with pelvic organ prolapse and among the diagnosed $28.6 \%$ had received treatment, $65.5 \%$ were aware regarding pelvic organ prolapse and age of having first child was significantly associated with the level of awareness ( $p=0.002)$.

Conclusion: In conclusion more than half of the women were aware regarding pelvic organ prolapse. Further awareness program can be conducted at rural settings by Female Community Health Volunteers and health workers to enhance the awareness level regarding pelvic organ prolapse among women.

Keywords: Awarenesses, pelvic organ prolapse, women

\section{INTRODUCTION}

Pelvic organ prolapse (POP) is the descent of one or more of the pelvic structures (bladder, uterus, vagina) from the normal anatomic location toward or through the vaginal opening. ${ }^{[1]}$ The condition usually occurs when the pelvic floor collapses as a result of childbirth or heavy lifting which can tear soft tissues, i.e. herniating fascia membranes so that the vaginal wall collapses, resulting in cystocele, rectocele or both these muscles and the surrounding tissues can get weak or stretched. ${ }^{[2]}$

Uterine prolapse leads to severe degrees of physical disability, including inability to work, difficulties walking or standing up, sitting, difficulties urinating or defecating, painful intercourse, increased social stigma, and economic deprivation. ${ }^{[3]}$ An estimated $13 \%$ (1 in 8) of US adult women will undergo surgery for POP by the age of 80 years, suggesting a great many more women will experience POP symptoms but may seek nonsurgical care or no interven- 
tion. ${ }^{[4]}$ Many studies have found that causes of POP in $\mathrm{Ne}-$ pal is the result of extensive physical labor, such as carrying heavy loads, especially during pregnancy and in postpartum period, prolonged labor during childbirth, forced delivery by untrained persons, lack of skilled birth attendants during delivery, low maternal weight due to malnutrition, lack of rest during postpartum period, insufficient spacing between births, bearing a large number of children with inadequate spacing. ${ }^{[5]}$

In one of the studies conducted to assess knowledge of uterine prolapse, it was revealed that $46.5 \%$ of respondents had adequate and $53.5 \%$ had inadequate knowledge about risks factors of uterus prolapse. ${ }^{[6]}$ Though various studies have been conducted on POP related topics in hilly regions and the eastern or western part of Nepal, very few have been conducted regarding awareness of POP in Terai and central part of Nepal. Thus, the study aims to assess the awareness regarding POP among women.

\section{METHOD}

The descriptive cross sectional study was conducted to assess the awareness regarding POP among 110 women selected via non probability consecutive sampling technique attending Gynaecology Outpatient Department (OPD) at Chitwan Medical College Teaching Hospital (CMCTH) available at the time of data collection. A standard tool named "Prolapse and Incontinence Knowledge Questionnaire" comprising of two distinct 12-item scales (Pelvic organ prolapse awareness questionnaire only taken) developed by Shah et al in 2008 was adopted to assess awareness on POP among women in this study and pretesting was done among 21 (10\% of sample size) respondents..$^{[7]}$ Reliability of the instrument was tested using internal consistency (Cronbach's alpha $>0.8$ ) and content validity was maintained through consultation with the subject expert and extensive literature review. Study was conducted after written permission taken from the administrator of CMCTH and HOD of Gynae department and Ethical approval was obtained from Chitwan Medical College Institutional Review Committee. Written informed consent was taken from each respondent prior to data collection after explaining the purpose of the study. The dignity of respondent was secured by giving right to reject or discontinue from the research study at any time. Privacy was maintained by taking face to face interview in a separate room. The researcher herself collected the data within 5 weeks duration ( $1^{\text {st }}$ of July to $5^{\text {th }}$ of August, 2018) and 25-30 minutes was allocated for each respondent. After field and central editing, organized data was entered by using IBM SPSS version 20.0 and was analyzed by using descriptive statistics in terms of (frequency, percentage, median, quartiles, and intra quartile range) and inferential statistics (Chi-square test, Continuity correction test, Fisher- exact test).

\section{RESULTS}

Among the women who were interviewed among those attending Gynae OPD at CMCTH belonged to age group 31-40 years with median age of 37.0 (22.0-75.0) years, 91 (82.7\%) were literate and 53 (47.3\%) were housewives. Regarding source of information related to POP, 54 (49.1\%) had heard from friends and relatives (Table 1). Among 110 women, $51(46.4 \%)$ were married between the ages of 16-19 years, 57 (51.8\%) had first child between the ages of 20-24 years whereas 86 (46.4\%) had two children and 37 (33.6\%) had abortion. Furthermore, $9(8.2 \%)$ respondents were found to have family history and 7 (6.4\%) respondents themselves had been diagnosed with POP among which only 2 (28.6\%) of them had received treatment including surgery (Table 2 ). The awareness level of 110 women showed that 72 (65.5\%)

\begin{tabular}{|c|c|c|}
\hline Variable & Frequency & Percentage \\
\hline \multirow{2}{*}{\multicolumn{3}{|c|}{$\begin{array}{l}\text { Source of information } \\
\text { (*multiple response) }\end{array}$}} \\
\hline & & \\
\hline Health Workers & 17 & 15.5 \\
\hline $\mathrm{FCHV}$ & 15 & 13.6 \\
\hline Friends and relatives & 54 & 49.1 \\
\hline Mass media & 28 & 25.5 \\
\hline Family members & 8 & 7.3 \\
\hline
\end{tabular}

Table 2. Respondents' family history and personal history of pelvic organ prolapse $(n=110)$

\begin{tabular}{|c|c|c|}
\hline Variables & Frequency & Percentage \\
\hline \multirow{2}{*}{\multicolumn{3}{|c|}{$\begin{array}{l}\text { Family history of pelvic organ } \\
\text { prolapsed }\end{array}$}} \\
\hline & & \\
\hline Yes & 9 & 8.2 \\
\hline No & 101 & 91.8 \\
\hline \multicolumn{3}{|c|}{ If positive history then relation } \\
\hline \multicolumn{3}{|c|}{ of respondents; $(n=9)$} \\
\hline Grandmother & 1 & 11.1 \\
\hline Mother & 8 & 88.9 \\
\hline \multicolumn{3}{|c|}{ Ever been diagnosed with pelvic } \\
\hline \multicolumn{3}{|l|}{ organ prolapse } \\
\hline Yes & 7 & 6.4 \\
\hline No & 103 & 93.6 \\
\hline \multirow{2}{*}{\multicolumn{3}{|c|}{$\begin{array}{l}\text { Received any treatment for pelvic } \\
\text { organ prolapse }(n=7)\end{array}$}} \\
\hline & & \\
\hline Yes & 2 & 28.6 \\
\hline No & 5 & 71.4 \\
\hline \multicolumn{3}{|l|}{ Type of treatment } \\
\hline Surgery & 2 & 28.6 \\
\hline
\end{tabular}


were aware and 38 (34.5\%) were unaware about POP (Table 3). A significant association was observed between their level of awareness and a single obstetric variable i.e. age of having first child (Table 4).

\section{DISCUSSION}

In this study $31.8 \%$ of women were found to be at the ages between $31-40$ years, $82.7 \%$ were literate and $47.3 \%$
Table 3. Respondents' Level of Awareness regarding Pelvic Organ Prolapse $(n=110)$

\begin{tabular}{lcc} 
Level of awareness & Frequency & Percentage \\
\hline Aware $(\geq 9)$ & 72 & 65.5 \\
Unaware $(<9)$ & 38 & 34.5 \\
\hline
\end{tabular}

Median $=9, \mathrm{IQR}=\left(\mathrm{Q}_{3}-\mathrm{Q}_{1}\right)=(10-8)$; minimum score $=5 ;$ maximum score $=12$.

Table 4. Association between respondent's level of awareness regarding pelvic organ prolapse and different variables $(n=110)$

\begin{tabular}{|c|c|c|c|c|}
\hline \multirow[t]{3}{*}{ Variables } & \multicolumn{2}{|c|}{ Level of awareness } & \multirow{3}{*}{$x^{2}$} & \multirow{3}{*}{$\mathbf{P}$} \\
\hline & & Aware & & \\
\hline & No (\%) & No (\%) & & \\
\hline$<37$ & $16(30.2)$ & $37(69.8)$ & 0.859 & 0.354 \\
\hline$\geq 37$ & $22(38.6)$ & $35(61.4)$ & & \\
\hline Others & $24(45.3)$ & $29(54.7)$ & & \\
\hline \multicolumn{5}{|l|}{ Education status } \\
\hline Literate & $28(30.8)$ & $63(69.2)$ & 3.23 & 0.068 \\
\hline Illiterate & $10(52.6)$ & $9(47.4)$ & & \\
\hline \multicolumn{5}{|l|}{ Type of occupation } \\
\hline Service & $2(22.2)$ & $7(77.8)$ & 0.199 & $0.656^{*}$ \\
\hline Non service & $36(35.6)$ & $65(64.4)$ & & \\
\hline \multicolumn{5}{|l|}{ Age of marriage } \\
\hline$<18$ & $18(40.0)$ & $27(60.0)$ & 1.002 & 0.317 \\
\hline$\geq 18$ & $20(30.8)$ & $45(69.2)$ & & \\
\hline \multicolumn{5}{|c|}{ Age of having 1st child } \\
\hline$<20$ & $22(52.4)$ & $20(47.6)$ & 9.558 & 0.002 \\
\hline$\geq 20$ & $16(23.5)$ & $52(76.5)$ & & \\
\hline \multicolumn{5}{|l|}{ Family history of POP } \\
\hline Yes & $1(11.1)$ & $8(88.9)$ & 1.386 & $0.239^{*}$ \\
\hline No & $37(36.6)$ & $64(63.4)$ & & \\
\hline \multicolumn{5}{|c|}{ Ever been diagnosed with POP } \\
\hline Yes & $2(28.6)$ & $5(71.4)$ & & $1.000 \#$ \\
\hline No & $36(35.5)$ & $67(65.0)$ & & \\
\hline
\end{tabular}

${ }^{*}$ continuity correction test used; \#fisher exact test used; Significance level at $\mathrm{p}$ value $<0.05$ 
were housewives. Regarding obstetric related information $46.4 \%$ had married between the ages of $16-19$ years, $51.8 \%$ had first child between the ages of 20-24 years. Regarding number of children $46.4 \%$ had two children and $33.6 \%$ had abortion. Regarding source of information related to pelvic organ prolapsed $49.1 \%$ had heard from friends and relatives. In this study, all of the women had heard about POP and more than half (65.5\%) were aware regarding POP. This finding is similar to the study conducted by Shrestha et al. in 2014 in Jhaukhel-Duwakot Health Demographic Surveillance Site, Bhaktapur where $93 \%$ of women had heard about uterine prolapse and $55 \%$ had comprehensive knowledge regarding uterine prolapse. ${ }^{[8]}$ The finding is also similar to the study conducted by Mandimika et al. in New Heaven Country where $51.9 \%$ of women had knowledge on POP ${ }^{[9]}$ However, the study conducted by El-sayed et al. in Tanta university and Menshway hospital, Egypt, reported that $56.5 \%$ of women hadn't heard about uterine prolapse and $95 \%$ had poor knowledge. ${ }^{[10]}$

Another similar study conducted by Shrestha et al. in 25 districts of Nepal revealed that $53 \%$ of women had never heard about uterine prolapse and knowledge level was satisfactory among $37 \%$ of those who had heard about it. ${ }^{[8]}$ Similarly, the study conducted by Karki and Neraula among Newar parous women at Bhaktapur reported that only 39\% were aware regarding uterovaginal prolapse. ${ }^{[11]}$ The differences in findings might be due to the difference in sample size, type of instrument and setting. In this study, $97.3 \%$ of the respondents responded correctly on both statements regarding symptoms of POP as pelvic heaviness or pressure and a good way for doctor to diagnose POP is by physically examining the patient. This finding is supported by similar study conducted by Shrestha et al. in Jhaukhel- Duwakot Health Demographic Surveillance Site, Bhaktapur using the same tool in which $84.5 \%$ and $84.4 \%$ had answered correctly for those statements respectively. ${ }^{[8]}$

This study found that there was significant association between the level of awareness and age of having first child. Awareness of POP increased with the increase in age of having first child. In this study, the type of occupation is not statistically significant with the level of knowledge. The findings of this study are similar to the study conducted by Singh et.al where age of having first child was significantly associated with the knowledge on uterine prolapsed and the level of knowledge was not significant with type of occupation ${ }^{[6]}$ In this study, there is no significant association between the level of knowledge and the level of education. This finding is supported by the similar study conducted by Shrestha et al. in 25 districts of Nepal revealing that the level of education was not associated with the level of knowledge. ${ }^{[8]}$

\section{CONCLUSION}

Based on the findings of the study, it is concluded that more than half of the women (65.5\%) attending Gynae OPD at $\mathrm{CMCTH}$ were aware regarding pelvic organ prolapsed and age of having first child was statistically significant with the level of knowledge. The findings cannot be generalized in other settings like in rural backward villages with illiterate women. Findings of this study can be a basis for instituting changes in health policies and programme design to include awareness regarding pelvic organ prolapsed into routine obstetrics and gynecology services in rural areas as well. The study findings can be helpful for nurses and other health personnel to plan and implement awareness programs. Similar studies can be conducted using larger samples in various settings for e.g. rural areas and can be carried out in different target populations like reproductive age woman. It can also be conducted among health workers as Female Community Health Volunteers, community health nurses because these are the most important person to aware and educate woman about POP at local levels.

\section{Disclosures}

Ethics Committee Approval: Ethical approval by Institutional Review Board of Chitwan Medical College.

Peer-review: Externally peer-reviewed.

Conflict of Interest: None declared.

Funding Source: There is no funding in this article.

Authorship Contributions: Concept - T.T., Su.S.; Design - T.T., Su.S.; Supervision - T.T.; Materials - T.T., Su.S.; Data collection \&/ or processing - Su.S., A.J., S.C., S.S.; Analysis and/or interpretation - T.T., S.S., A.J., S.C, Su.S.; Literature search - Su.S., A.J., S.C., S.S.; Writing - S.S., A.J., S.C., Su.S.; Critical review - T.T., S.S., S.C., A.J.

\section{REFERENCES}

1. Kuncharapu I, Majeroni BA, Johnson DW. Pelvic organ prolapse. Am Fam Physician 2010;81(9):1111-7.

2. Muthusamy H, Aldajah S, Sivanandan Ramar A. Comparison of Cardiovascular Response between Men and Women to Isometric Exercise of Lower Limb. International Journal of Health and Rehabilitation Sciences 2015;4(3):193-200. [CrossRef]

3. Sharma A, Zhang JP. Risk Factors and Symptoms of Uterine Prolapse: Reality of Nepali Women. Asian Women 2014;30(1):81-95.

4. Bradley CS. Progress toward understanding pelvic organ prolapse. Am J Obstet Gynecol 2018;218(3):267-8. [CrossRef]

5. Gurung G, Rana A, Amatya A, Bista KD, Joshi AB, Sayami J. Pelvic organ prolapse in rural Nepalese women of reproductive age groups: What makes it so common?. Nepal Journal of Obstetrics and Gynaecology 2007;2(2):35-41. [CrossRef]

6. Singh DR, Lama S, Maharjan S. Knowledge on risk factors of 
uterine prolapse among reproductive age group women of Bajrabarahi Municipality of Lalitpur, Nepal. Int J Reprod Contracept Obstet Gynecol 2016;5(10):3343-8. [CrossRef]

7. Shah AD, Massagli MP, Kohli N, Rajan SS, Braaten KP, Hoyte L. A reliable, valid instrument to assess patient knowledge about urinary incontinence and pelvic organ prolapse. Int Urogynecol J 2008;19(9):1283. [CrossRef]

8. Shrestha B, Choulagai B, Onta S, Shrestha KB, Petzold M, Krettek A. Knowledge, prevalence and treatment practices of uterine prolapse among women of reproductive age in the Jhaukhel-Duwakot Health Demographic Surveillance Site, Bhaktapur, Nepal. Journal of Kathmandu Medical College
2014;3(4):136- 43. [CrossRef]

9. Mandimika CL, Murk W, McPencow AM, Lake A, Wedderburn T, Collier $\mathrm{CH}$, et al. Knowledge of pelvic floor disorders in a population of community-dwelling women. Am J Obstet Gynecol 2014;210(2):165.e1-9. [CrossRef]

10. Elsayed FM, Ahmed MH, Gaheen MASA. Knowledge and Practices of women regarding Risk Factors of Uterine Prolapse. IOSR Journal of Nursing and Health Science (IOSR-JNHS) 2016;5(6):60-7.

11. Karki S, Neraula A. Awareness regarding uterovaginal prolapse among Newar parous women. International Journal of Nursing Education 2015;7(1):144-9. [CrossRef] 